\title{
EKSISTENSI PENDIDIKAN LINGKUNGAN HIDUP DALAM RANAH PENDIDIKAN ISLAM
}

\author{
Irham Fajriansyah, Uswatun Hasanah, Ali Murtadho \\ Universitas Islam Negeri Raden Intan Lampung \\ Irhamfajriansyah1@gmail.com \\ uswatunh@radenintan.ac.id \\ alimurtadho79@yahoo.co.id
}

\begin{abstract}
The current environmental issues are part of a global crisis that often becomes a concern of discussion in the world stage. Various approaches have been taken to resolve the crisis, but the results are still debatable. One of the most ideal approaches is to use an Islamic education approach. This research aims to examine the existence of environmental education in Islamic education. This research is a literature research with documentation methods and use content analysis for its analytical techniques. The results of research shows that Islamic education can be used as a means to realize the values of environmental education, because there is a close relationship between environmental education and Islamic education, such as from the material, methods and goals aspects that ultimately achieve the goal of forming awareness of each individual to the environment issues.
\end{abstract}

\section{Keywords: Education, Environmental, Islamic Education}

\begin{abstract}
Abstrak
Krisis lingkungan yang saat ini terjadi merupakan bagian dari krisis global yang sering menjadi perbincangan di dunia. Berbagai pendekatan telah dilakukan untuk menyelesaikan krisis tersebut, namun hasilnya masih belum terlihat jelas. Salah satu pendekatan yang di anggap paling ideal adalah dengan menggunakan pendekatan pendidikan Islam. Penelitian ini bertujuan untuk mengkaji eksistensi pendidikan lingkungan hidup dalam ranah pendidikan Islam. Penelitian ini merupakan penelitiaan kepustakaan dengan metode dokumentasi dan teknik analisa yang digunakan adalah analisis isi. Berdasarkan hasil penelitian menunjukkan bahwa pendidikan Islam dapat dijadikan sebagai sarana untuk merealisasikan nilai-nilai pendidikan lingkungan hidup, karena terdapat hubungan yang erat antara pendidikan lingkungan hidup dengan pendidikan Islam yaitu dari aspek materi, metode juga tujuan yang hasil akhirnya mencapai tujuan yaitu terbentuknya kesadaran setiap individu terhadap lingkungan hidup.
\end{abstract}

Kata Kunci: Pendidikan, Lingkungan Hidup, Pendidikan Islam. 


\section{PENDAHULUAN}

Manusia merupakan mahluk ciptaan yang sempurna, dengan akalnya Allah SWT memberikan suatu tugas atau amanat yang diberikan oleh Allah SWT kepada manusia yaitu untuk menjadi khalifah yang berarti pengganti ataupun pemimpin di muka bumi ini. Akan tetapi, kesadaran manusia yang menitik beratkan posisinya sebagai khalifah menyebabkan umat manusia merasa yang paling berhak untuk menguasai bumi dan mengeksploitasinya secara berlebih-lebihan dan terus menerus sehingganya menimbulan kerusakan pada alam sekitarnya. Bagi manusia, alam adalah sumber daya yang dapat dieksploitasi secara maksimal untuk kepentingan manusia, dan untuk dapat mencapai tujuannya alam harus di kuasai, sikap ingin menguasai dan mengeksploitasi alam sebesar-besarnya inilah yang kemudian menjadi sumber terjadinya krisis lingkungan.

Krisis lingkungan yang saat ini terjadi menjadi banyak perbincangan di media massa baik cetak maupun elektronik, karena masalah tersebut dapat mengancam kehidupan manusia di alam ini dengan berupa bencana alam seperti banjir, gempa bumi, tanah longsor, kekeringan. Fenomena tersebut timbul di samping faktor alami dari alam tentunya ada faktor yang disebabkan oleh manusia itu sendiri seperti perusakan pada alam sehingganya alam tidak dapat berfungsi sebagaimana mestinya. Permasalahan yang paling utama dalam lingkungan hidup ini adalah adanya ketidakserasian serta ketidakseimbangan yang di timbulkan oleh perbuatan manusia itu sendiri, manusia ingin memenuhi kebutuhan hidupnya namun tidak melihat sisi keserasian dan ketidakseimbangan pada alam, akibatnya manusia melakukan eksploitasi secara berlebih-lebihan demi untuk memenuhi kebutuhan hidupnya, sehingganya terjadi kerusakan pada alam tersebut oleh tindakan manusia itu sendiri. ${ }^{1}$

Berbagai cara telah dilakukan untuk menyelamatkan lingkungan hidup, baik yang dilakukan oleh masyarakat maupaun pemerintah, dengan menggunakan berbagai macam pendekatan yang telah dilakukan. Namun, hasilnya belum maksimal sebagaimana yang telah diharapkan. Oleh karenanya, dibutuhkan pendekatan yang cocok pada masyarkat untuk menekan laju kerusakan lingkungan hidup yang saat ini terjadi. Salah satu pendekatan yang dinilai paling tepat adalah dengan pendekatan pendidikan, sebab sejak zaman lampau, pendidik telah digunakan sebagai sarana pembinaan dan penanamaan nilai-nilai termasuk sikap religiusitas pada manusia yang dinilai dapat mencegah tindakan-tindakan yang dapat merusak lingkungan hidup.

Pendidikan Islam sebagai Pendidikan yang berlandaskan ajaran Islam yang merupakan agama rahmatan lil 'alamin, Islam tidak hanya menjaga hubungan antara manusia dengan Allah SWT (Habblun Mina 'Allah) dan hubungan manusia dengan manusia (Habblun Mina 'nas), tetapi Islam juga memperhatikan hubungan manusia dengan alam (Habblun Minal 'alam). Menjaga alam atau lingkungan hidup termasuk

${ }^{1}$ Ali Yafie, Merintis Fiqh Lingkungan Hidup, ed. Marzuki Wahid, Helmy Ali, and Marya Ulfa, 1st ed. (Jakarta: Yayasan Amanah Ufuk Press, 2016).h.6

16 | Qiro'ah| Vol. 11 No. 22021 
kedalam salah satu tujuan pokok syariah (maqashid al-Syaria'ah). ${ }^{2}$ Pendidikan Islam bukan hanya sebatas pada akhirat saja tetapi juga memperhatikan aspek dunia. Namun dalam pelaksanaanya, pendidikan Islam masih terdapat kesenjangan yang hanya menitik beratkan kepada hubungan manusia dengan Allah (Habblun Mina Allah) dan hubungan manusia dengan manusia (Habblun Mina Nas) saja, sementara hubungan manusia dengan alam (Habblun Mina 'Alam) masih kurang untuk ditekankan, padahal hal tersebut tidak kalah pentinganya untuk ditekankan pada pendidikan Islam. Akibatnya tindakan-tindakan perusakan pada lingkungan hidup marak terjadi, dan hal tersebut tentunya sudah melanggar amanat dari Allah SWT yang menugaskan setiap individu sebagai khalifah fil ard yang seharusnya bisa menjaga dan merwatnya, bukan justru untuk merusaknya.

Penelitian mengenai lingkungan hidup sebelumnya sudah banyak dilakukan oleh para peneliti sebelumnya dengan menggunakan pendekatan agama Islam. ${ }^{3}$ Penelitian terdahulu tersebut membahas mengenai konsep pendidikan lingkungan dengan pandangan Islam. Dalam penelitian tersebut berfokus pada pembahasan untuk memaparkan tujuan serta implimentasi pendidikan lingkungan hidup di sekolah serta etika dan konservasi lingkungan dalam perspektif Islam. Sedangkan, dalam penelitian ini bertujuan untuk mengkaji eksistensi Pendidikan lingkungan hidup dalam ranah Pendidikan Islam.

\section{METODE PENELITIAN}

Metode penelitian yag digunakan adalah kualitatif deskriptif yang merupakan jenis penelitian studi pustaka (Library Reseacrh) yaitu penelitian yang dilakuakan melalui pengumpulan data dan menganalisisnya untuk kemudian diinterpretasikan dan dinarasikan. Suatu penelitian yang tidak meneliti angka melainkan dengan menghimpun dan menganalisis data berupa buku-buku, jurnal penelitian, artikel dan sumber informasi lainnya termasuk sumber informasi online, yang dapat dijadikan sumber rujukan dalam menyusun penelitian ini. ${ }^{4}$ Teknik pengumpulan data yang digunakan adalah dokumentasi dengan teknik analisa menggunakan analisis isi (content analysis).

${ }^{3}$ Yusuf Qardhawi, Riayah Al Bi'ah Fi Syari'ati Al-Islam (Cairo: Daar al-Syuruq, 2001).h.51

${ }^{4}$ Abdurrahmat Fathoni, Metodologi Penelitan Dan Penyusunan Skripsi (Jakarta: Rineka Cipta, 2011).h.159

17 | Qiro'ah| Vol. 11 No. 22021 


\section{HASIL DAN PEMBAHASAN}

\section{Menyelami Makna Konsep Pendidikan Lingkungan Hidup}

Pendidikan lingkungan hidup adalah usaha yang dilakukan untuk membina, membimbing, mengajarkan setiap individu agar memiliki kesadaran dalam dirinya untuk peduli terhadap lingkungannya secara keseluruhan sebagai upaya memecahkan permasalahan lingkungan yang terjadi ketika setiap individu memiliki pengetahuan, keterampilan, sikap dan tingkah laku, motivasi dan mampu untuk bergotong royong sehingga akan terbentuk suatu kumpulan masyarakat yang dapat bekerjasama menyelesaikan permasalahan limgkungan dan mampu melakukan pencegahan agar tidak terjadi masalah yang baru. ${ }^{5}$

Berdasarkan pengertiannya maka dapat difahami bahwa Pendidikan lingkung hidup tidak hanya mengajarkan tentang ilmu menjaga lingkungan akan tetapi lebih dari itu yaitu berusaha menyadarkan manusia akan urgensi menjaga lingkungan hidup dan implikasinya. Adapun tujuan Pendidikan lingkungan hidup secara bertahap peneliti gambarkan sebagai berikut:
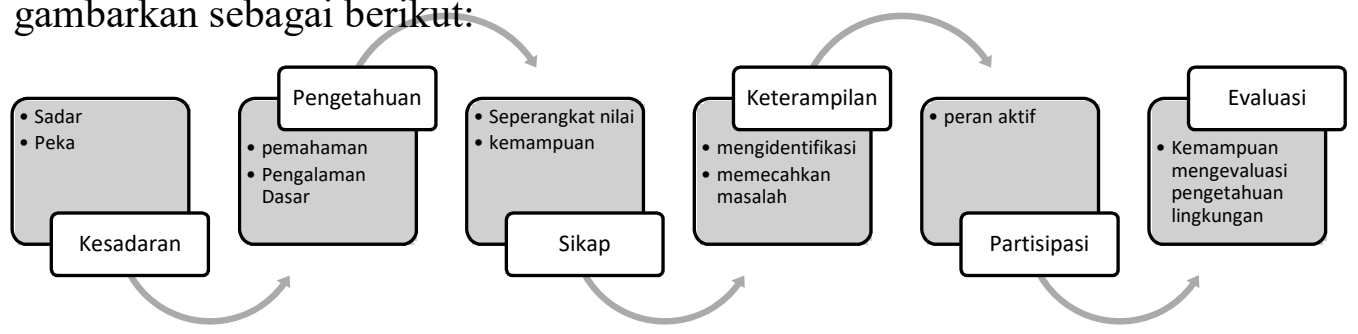

Gambar 1. Tujuan Pendidikan Lingkungan Hidup

Gambaran tentang tujuan Pendidikan lingkungan hidup di atas menjelaskan beberapa aspek yang ingin dicapai dalam pelaksanaan Pendidikan lingkungan hidup yaitu : Pertama, Kesadaran, Pendidikan lingkungan hidup dilaksanakan sebagai upaya untuk membangun kesadaran dan kepedulian masing-masing individu terhadap lingkungan dan permasalahan lingkungannya. Kedua, pengetahuan, yaitu membina setiap individu untuk mendapatkan berbagai pengalaman dan pemahaman dasar tentang lingkungan dan masalahnya. Ketiga, sikap, yaitu membimbing setiap individu agar mendapatkan nilai-nilai sehingga dengan nilai-nilai tersebut dapat membangun kepekaan dalam dirinya terhadap lingkungan dan berupaya memberikan dorongan motivasi untuk memiliki peran aktif dalam peningkatan dan perlindungan lingkungan. Keempat, setelah nilai-nilai kesadaran dan kepedulian tertanam pada setiap individu dan memiliki motivasi yang kuat selajutnya individu tersebut akan memiliki keterampilan dalam mengidentifikasi dan memecahkan masalah lingkungan. Kelima, Partisipasi, yaitu berupaya untuk mendorong setiap individu agar berperan aktif dalam

${ }^{5}$ Daryanto Daryanto and Agung Suprihatin, Pengantar Pendidikan Lingkungan Hidup (Yogyakarta: Gava Media, 2013).h.2

18 | Qiro'ah| Vol. 11 No. 22021 
pemecahan masalah lingkungan. Keenam, evaluasi, yaitu mendorong setiap individu agar memiliki kemampuan mengevaluasi pengetahuan lingkungan ditinjau dari segi ekologi, sosial, ekonomi, politik, dan faktor-faktor pendidikan. ${ }^{6}$

Berdasarkan pendapat diatas disimpulkan bahwa tujuan pendidikan lingkungan hidup yaitu terciptanya kesadaran pada setiap individu yang selanjutnya melahirkan kepedulian pada lingkungan dan hasil akhirnya memilki motivasi untuk bertindak menjaga dan memecahkan permasalahan lingkungan yang terjadi disekitarnya. Bila dicermati tujuan yang ingin diwujudkan oleh pendidikan lingkungan hidup yang telah dikemukakan terdahulu, maka secara substansi, cakupan pokok materi bahasan pendidikan lingkungan hidup peneliti gambarkan sebagai berikut:

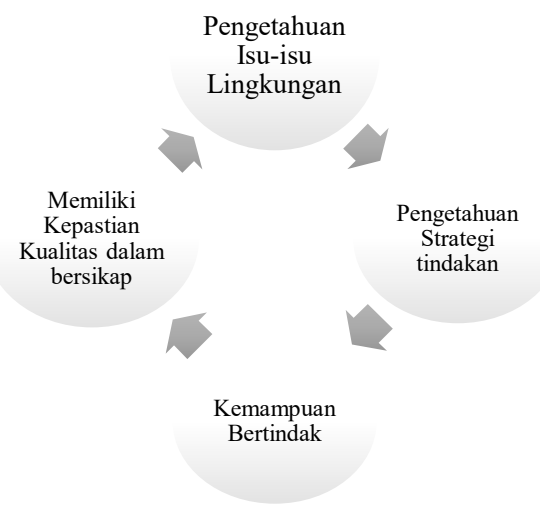

Gambar 2. Materi Pokok dalam Pendidikan Lingkungan Hidup.

Keseluruhan materi pokok bahasan meliputi pengetahuan-pengetahuan dasar terkait isu-isu lingkungan, pengetahuan tentang strategi tindakan yang dapat dilakukan ketika menghadapi permasalahan lingkungan, kemampuan untuk bertindak menjaga ataupun menyelesaikan permasalahan lingkungan yang terjadi dan memiliki kepastian kualitas dalam bertindak menjaga maupun mencari solusi pemecahan masalah lingkungan. Semua materi ini secara tidak langsung juga menggambarkan keterkaitan yang sangat erat dan sangat sulit untuk dipisahkan sebagai bahasan yang berdiri sendiri. $^{7}$

Perkembangan penyelenggaraan pendidikan lingkungan hidup dimulai pada tahun 1975 di mana Institut keguruan Ilmu Pendidikan (IKIP) jakarta lalu diujicobakan di 15 Sekolah Dasar jakarta pada periode tahun 1975-1978. Pada tahun 1979 dibentuk dan berkembang pusat studi Lingkungan Hidup (PSL) di berbagai perguruan tinggi negeri dan swasta. Bersama dengan itu, mulai dikemabangkan pendidikan Analisis

\footnotetext{
${ }^{6}$ Daryanto Daryanto and Agung Suprihatin, Pengantar Pendidikan Lingkungan Hidup (Yogyakarta: Gava Media, 2013).h.3

${ }^{7}$ Syukri Hamzah, "Pendidikan Lingkungan : Sekelumit Wawasan Pengantar" (Bandung: Refika Aditama, 2013).h.49
}

19 | Qiro’ah| Vol. 11 No. 22021 
Mengenai Dampak Lingkungan (AMDAL) oleh semua PSL di bawah koordinasi Menteri Negara Pengawasan Pembangunan dan Lingkungan Hidup (Meneg PPLH). Hingga tahun 2002, jumlah PSL yang menjadi anggota Badan Koodinasi Pusat Studi Lingkungan (BKPSL) telah berkembang menjadi 87 PSL dan di samping itu berbagai perguruan tinggi baik negeri maupun swasta mulai membentuk program khusus lingkungan hidup seperti fakultas kehutanan, Institut Pertanian Bogor. ${ }^{8}$

Pada jenjang pendidikan dasar dan menengah, penyampaian mata ajar tentang masalah kependudukan dan lingkungan hidup secara integratif dituangkan dalam sistem kurikulum tahun 1984 dengan memasukkan masalah-masalah kependudukan dan lingkungan hidup kedalam hampir semua mata pelajaran. Sejak tahun 1989/1990 sampai saat ini berbagai pelatihan tentang lingkungan hidup telah diperkenalkan oleh Departemen Pendidikan Nasional bagi guru-guru SD, SMP, SMA termasuk sekolah kejuruan. Prakarsa pengembangan pendidikan lingkungan juga dilakukan oleh berbagai Lembaga Swadaya Masyarakat (LSM). Pada tahun 1996/1997 terbentuk Jaringan Pendidikan Lingkungan (JPL) yang beranggotakan LSM-LSM yang berminat dan menaruh perhatian terhadap pendidikan lingkungan, hingga tahun 2001 tercatat 76 anggota JPL yang bergerak dalam pengembangan dan pelaksanaan pendidikan lingkungan. ${ }^{9}$

\section{Sekilas Tentang Konsep Pendidikan Lingkungan Hidup perspektif Islam}

Pendidikan lingkungan hidup dalam perspektif Islam adalah suatu bentuk usaha untuk membangun manusia di dunia untuk memiliki kesadaran dan kepedulian terhadap lingkungan secara menyeluruh termasuk semua permasalahan mengenai lingkungan hidup, serta mewujudkan masyarakat yang memiliki pengetahuan, keterampilan, sikap dan tingkah laku dengan didasari oleh alam adalah ciptaan Allah SWT, Manusia adalah khalifah Allah SWT di bumi dan manusia tidak boleh melakukan kerusakan pada lingkungan hidupnya, dengan bersumber pada ajaran-ajaran Islam. ${ }^{10}$

Atas dasar pendapat di atas pendidikan lingkungan yang diajarkan secara Islami merupakan sarana penting bagi setiap muslim untuk mengenal dan menyadari lingkungan hidup mereka secara baik dan benar, sehingga mampu berperan secara sadar dan aktif dalam pengelolaan dan pembinaan lingkungan. Sebagai mayoritas penduduk Islam, tentunya setiap muslim mempunyai kewajiban serta peran yang sangat besar dalam pengelolaan lingkungan. Dibutuhkan pengetahuan dan kesadaran yang mendalam bahwa Islam sangat memperhatikan lingkungan hidup. Hal ini membutuhkan peran pendidik, ulama, dan tokoh masyarakat untuk menanamkan pengetahuan dan kesadaran tersebut kepada masyarakat. Kesadaran bahwa alam semesta ini diciptakan dan milik Allah SWT meruapakan langkah yang paling dasar

\footnotetext{
${ }^{8}$ Daryanto and Suprihatin, Pengantar Pendidikan Lingkungan Hidup.

${ }^{9}$ Ibid.

${ }^{10}$ Agus Sulistiyo, “Konsep Pendidikan Lingkungan Hidup Dalam Pandangan Islam," Jurnal Cahaya Pendidikan 4, no. 1 (2018), https://doi.org/https://doi.org/10.33373/chypend.v4i1.1281.

20 | Qiro'ah| Vol. 11 No. 22021
} 
dalam memahami kedudukan manusia di alam ini. Lebih lanjut perlunya suatu cara pandang yang memposisikan manusia hanya sebagai pengelola, dan bukan memposisikan dirinya sebagai pemilik mutlak yang merasa paling berhak untuk mengeksploitasi alam hingga habis. Dengan cara pandang tersebut diharapkan kelestarian pada lingkungan dan keseimbangannya akan terjaga dengan baik.

Adapun Tujuan pendidikan lingkungan hidup perspektif Islam yaitu untuk menyadarkan manusia selaku khalifah dalam mengelola sumber daya alam harus secara bijaksana, dan menumbuhkan rasa tanggung jawab terhadap kepentingan generasi yang akan datang, dan untuk menjaga keberlangsungan kehidupannya. ${ }^{11}$ Uuntuk mewujudkan hal tersebut diperlukan pengetahuan, sikap serta keterampilan atau perilaku yang bisa membuat sumber daya alam yang ada di alam ini tetap dapat dimanfaatkan secara berkelanjutan. Inti dari tujuan Pendidikan lingkungan hidup perspektif Islam adalah untuk menyadarkan manusia bahwa segala tindakan yang dapat menimbulkan kerusakan pada alam atau lingkungan adalah suatu tindakan yang dilarang dan tercela. sebagaimana dijelaskan dalam Al-Qur'an surat Al-Qasas [28]: 77 yang menjelaskan bahwa sudah sangat jelas bahwa Allah SWT melarang umat manusia untuk berbuat kerusakan di muka bumi.

Maka pendidikan lingkungan hidup perspektif Islam memiliki tugas untuk mengingatkan manusia agar menjaga dan peduli terhadap lingkungannya, dan tidak melakukan tindakan-tindakan yang dapat menimbulkan kerusakan pada lingkungan hidup. Adapun Lingkup materi pendidikan lingkungan hidup perspektif Islam yaitu :

1. Pengetahuan tujuan penciptaan alam semesta dan peran manusia di muka bumi ini sebagai khalifah.

Pengetahuan penciptaan alam semesta serta peran manusia di muka bumi sangat penting dalam pendidikan lingkungan hidup dalam perspektif Islam, tujuan utama penciptaan adalah untuk menyediakan kumpulan "tanda (ayat)" kepada manusia untuk mengimani Allah SWT, manusia tidak memiliki dalih untuk tidak mengimani Allah SWT, karena di alam ini penuh akan tanda-tanda kebesaran Allah SWT. Serupa dengan hal tersebut, tujuan penciptaan adalah untuk membimbing manusia dan untuk menguji iman serta tindakan manusia itu sendiri. ${ }^{12}$ jika manusia paham akan tujuan penciptaan dan peran manusia di bumi ini dan diimplementasikan dalam kehidupan sehari-hari, maka kuasa manusia atas ciptaan Allah SWT yang ada di alam ini akan menjadi sebuah tanggung jawab dengan memperhatikan lingkungan yang menjadi milik Allah.

2. Prinsip pemanfaatan sumber daya alam dalam perspektif Islam

Sumber daya alam yang ada di alam ini diciptakan oleh Allah SWT untuk manusia sebagai bentuk kasih sayang Allah SWT kepada manusia. Namun, semua

\footnotetext{
${ }^{11}$ Purwidianto Purwidianto, "Pendidikan Lingkungan Hidup Dalam Perspektif Islam," Jurnal UHAMKA 8, no. 2 (2017): 205-28, https://doi.org/10.36835/syaikhuna.v11i1.3844.

${ }^{12}$ Herman Khaeron, Islam, Manusia, Dan Lingkungan Hidup: Kontekstualisasi Ajaran Islam Dalam Mengelola Alam Semesta., ed. Irwan Kurniawan, 1st ed. (Bandung: Nuansa Cendikia, 2014).h.17 21 | Qiro'ah| Vol. 11 No. 22021
} 
nikmat itu merupakan titipan dan hak pakai manusia untuk mengelola bumi, bukan menjadi hak milik yang boleh diperlakukan secara sewenang-wenang dengan sesuka hati tanpa mematuhi aturan, tata cara dan norma-norma yang telah ditetapkan. ${ }^{13}$

3. Pengetahuan mengenai akhlak manusia terhadap alam.

Dalam menjalankan perannya sebagai khalifah fil ard maka akhlak manusia terhadap lingkungan juga berfungsi sebagai panduan untuk manusia untuk mengembangakan hubungan dengan alam. Seseorang yang paham dan mengimplementasikan akhlak terhadap lingkungan tidak akan menjadikan lingkungan sebagai bagian subsistem kehidupannya sehingga dengan mudahnya untuk mengeksploitasi lingkungan, tetapi dipandang sebagai sesama mahluk yang memiliki kedudukan yang sama dihadapan Allah SWT sehingga keberadaannya dilindungi oleh manusia. Oleh sebab itu, akhlak terhadap lingkungan ini masuk kedalam lingkup materi pendidikan lingkungan hidup perspektif Islam melihat fungsinya begitu amat penting. ${ }^{14}$

Prinsip pendidikan lingkungan hidup perspektif Islam. Dalam Pendidikan lingkungan hidup terdapat beberapa prinsip yang harus ditanamkan dalam pendidikan lingkungan hidup perspektif Islam, untuk menumbuhkan kesadaran manusia dalam berhubungan dengan lingkungan hidup secara baik dalam kehidupan keseharaiannya. Berikut ini adalah prinsip-prinsip yang dapat menjadi pegangan dan tuntunan untuk membangun kesadaran bagi manusia dalam berinteraksi dengan lingkungan hidup:

a. Sikap hormat terhadap alam

Dalam fikih sebagaimana mengutip pendapat Ali Yafie ada suatu ketentuan dasar bahwa, semua mahluk hidup yang ada di bumi ini memiliki status hukum muhtaram, bukan dalam arti terhormat, namun harus dilindungi keberadaannya. Jika sesama mahluk hidup maka tidak boleh membunuh tanpa sebab yang jelas, jika mahluk itu tidak bernyawa maka tidak boleh untuk merusaknya. Semua mahluk harus dilindungi dan di hormati keberadaanya. dalam Al-Qur'an Surat A1 Anbiya [21]: 107. Dijelaskan bahwa Rahmatan lil alamin dalam ayat ini bukan hanya sekedar motto bagi agama Islam, tetapi merupakan tujuan dari Islam itu sendiri.

b. Prinsip Tanggung Jawab

Terkait dengan prinsip ini yaitu terkait dengan tanggung jawab moral terhadap alam, kerena manusia diciptakan menjadi khalifah dimuka bumi ini sesuai dengan firman Allah SWT, dalam surat QS. Al- Baqarah [2]: 30. Berdasarkan kenyataan yang dijelaskan pada ayat ini melahirkan sebuah prinsip moral bahwa manusia mempunyai tanggung jawab baik terhadap alam semesta seluruhnya dan

\footnotetext{
${ }^{13}$ Erwati Aziz, "Upaya Pelestarian Lingkungan Hidup Melalui Pendidikan Islam” (Yogyakarta: Pustaka Pelajar, 2013).h.13

${ }^{14}$ Muhiddin Mawardi, Gatot Supangkat, and Miftahulhaq Miftahulhaq, "Akhlaq Lingkungan : Panduan Berperilaku Ramah Lingkungan," Kementerian Lingkungan Hidup 1 (2011), h.56.
}

22 | Qiro'ah| Vol. 11 No. 22021 
intergitasnya, setiap benda yang diciptakan Allah SWT di alam semesta ini dengan tujuan masing-masing, terlepas dari apakah tujuan itu untuk kepentingan manusia ataupun bukan. Oleh sebab itu, manusia sebagai bagian dari mahluk yang ada di alam semesta ini ataupun bagian dari ekosistem ini bertanggung jawab juga untuk menjaganya.

c. Prinsip Kasih Sayang dan Kepedulian Terhadap Alam

Manusia sebagai sesama anggota komunitas ekologis yang setara, manusia diperintahkan untuk menyayangi serta melestarikan alam beserta seluruh isinya, tanpa diskriminasi serta tanpa dominasi dari manusia itu sendiri. Kasih sayang dan kepedulian juga muncul dari kenyataan bahwa sebagai sesama anggota komunitas ekologis, semua mahluk hidup yang ada di alam ini memiliki hak untuk dilindungi, dipelihara, dirawat, serta tidak saling menyakiti, dari sesuatu yang yang dapat merubah, mencemari, ataupun merusaknya.

Nabi Muhammad Saw. bersabda dalam hadistnya terkait kasih sayang dan kepedulian terhadap alam yang artinya: "Dari Abdullah Ibn Umar RA, bahwasannya Rasulullah SAW bersabda: Seorang perempuan masuk neraka karena seekor kucing yang ia kurung hingga mati, maka dari itu ia masuk neraka karena kucing tersebut, disebabkan ia tidak memberinya makan dan tidak pula memberinya minum di saat ia mengurungnya, dan tidak pula ia membiarkannya memakan serangga tanah". ${ }^{15}$ Hadist dengan jelas menerangkan bahwasannya Nabi Muhammad Saw. memerintahkan umatnya untuk tidak boleh bertindak menyakiti mahluk hidup baik itu hewan maupun tumbuhan, mereka harus memiliki kasih sayang terhadap semua mahluk yang ada di alam ini, untuk itu prinsip kasih sayang dan kepedulian terhadap alam perlu ditanamkan kepada manusia dalam pendidikan lingkungan hidup perspektif Islam ini, agar mereka memiliki tata kelola yang baik dengan alam.

d. Prinsip Kesederhanaan

Allah SWT telah mengizinkan manusia untuk menikmati rezeki yang telah disediakan oleh Allah SWT di bumi ini, namun dalam menikmati nikmat hal tersebut, tidak boleh secara berlebihan melainkan dengan kesederhanaan untuk menjaga keseimbangan pada alam. Karena kerusakan pada lingkungan hidup yang sering terjadi banyak disebabkan oleh ulah manusia dengan gaya hidup yang konsumtif dan eksploitatif. ${ }^{16}$ Dalam QS. Al-A'raf [7]: 31). Menjelaskan bahwa manusia tidak boleh bergaya hidup secara berlebih-lebihan. Oleh sebab itu, pola gaya hidup secara sederhana harus tertanam dalam setiap manusia untuk menjaga lingkungan dari krisis lingkungan, seperti menghemat pemakaian sumber daya alam dengan mempertimbangkan dampak yang ditimbulkan jika pemakaian

\footnotetext{
${ }^{15}$ Muhammad bin Ismail al-Bukhari , Al- Jami' As-Shahih, (Beirut: Dar Ibn Hazm), hlm. 862

${ }^{16}$ Aziz Ghufron and Saharudin Saharuddin, "Islam Dan Konservasi Lingkungan (Telaah Pemikiran Fikih Lingkungan Yusuf Al-Qardhawi)," Millah VI, no. 2 (2007): 55-75.
}

23 | Qiro'ah| Vol. 11 No. 22021 
sumber daya alam secara berlebihan. Karena bagaimanapun, sumber daya alam yang diciptakan oleh Allah SWT di alam ini bukan hanya untuk dimanfaatkan oleh manusia, akan tetapi mahluk lainpun berhak untuk memanfaatkannya.

e. Prinsip Keadilan dan Kebaikan

Prinsip ini harus ditanamkan dalam pendidikan lingkungan hidup dalam perspektif Islam, karena keadilan dan kebaikan harus dimilki oleh manusia, baik dalam berhubungan dengan manusia maupun dengan alam. Manusia harus menerima peran sebagai pelindung planet ini dari berbagai tindakan maupun perilaku yang dapat merusak dan merugikan. Sekian lama alam atau lingkungan telah menjadi sasaran eksploitatif dari manusia, dan sebagian manusia itu hanya untuk mengejar kepentingan pribadi ataupun keuntungan material saja. Oleh karena itu, manusia harus memiliki prinsip keadilan dan kebaikan dalam berhubungan dengan alam, memperlakukan alam tidak hanya sebatas bahwa manusia adalah mahluk yang paling berhak untuk menguasai alam ini, padahal ada mahluk lain yang tinggal dan hidup di alam ini selain manusia itu sendiri. ${ }^{17}$ manusia tidak boleh berlaku sewenang-wenang, bersikap angkuh, dan bercita-cita untuk menguasai bahkan menaklukan alam semesta untuk kepentingan sendiri, oleh karena itu prinsip keadilan dan kebaikan harus ditanamkan pada manusia melalui pendidikan lingkungan hidup perspekti Islam ini, agar manusia bisa memperlakukan alam di dalamnya secara akrab, dan menjadikan alam menjadi bagian dari hidupnya.Berdasarkan prinsip-prinsip di atas, memiliki suatu kesamaan dengan pendidikan Islam terutama pada hal prinsip-prinsip dalam tujuan pendidikan Islam yaitu prinsip universal (syumuliyyah) dan prinsip keseimbangan dan kesederhanaan (tawazun wa iqtishadiyyah). ${ }^{18}$

Dalam prinsip tersebut, memandang bahwa keseluruhan aspek agama (akidah, ibadah, akhlak dan muamalah) manusia, masyarakat dan tatanan kehidupannya, serta adanya wujud lingkungan hidup. Prinsip-prinsip tersebut mewujudkan formulasi tujuan pendidikan dengan membuka, mengembangkan dan mendidik segala aspek pribadi manusia untuk menyelesaikan semua masalah, dalam kaitannya dengan pendidikan lingkungan hidup yaitu masalah-masalah yang berkaitan dengan lingkungan hidup saat ini terjadi, karena hal itu erat hubungannya dengan tindakan manusia terhadap lingkungan atau akhlak manusia terhadap lingkungan.

\footnotetext{
${ }^{17}$ Ibrahim Abdul Matin, Greendeen: Inspirasi Islam Dalam Menjaga Dan Mengelola Alam, 1st ed. (Jakarta: Zaman Press, n.d.).h.31-32

${ }^{18}$ Bukhari Umar, Ilmu Pendidikan Islam, 1st ed. (Jakarta: Amzah, 2018).h.53
}

24 | Qiro'ah| Vol. 11 No. 22021 


\section{Eksistensi Pendidikan Lingkungan Hidup Dalam Ranah Pendidikan Islam}

Pendidikan lingkungan hidup memiliki hubungan dengan pendidikan Islam, kendala utama dalam menyelamatkan lingkungan adalah kurangnya kesadaran manusia akan perlunya pelestarian lingkungan hidup. Dalam hal ini pendidikan Islam dapat dijadikan sebagai media untuk pemecahannya, dapat peneliti gambarkan relevansi pendidikan lingkungan hidup dengan pendidikan Islam dalam bagan dibawah ini:

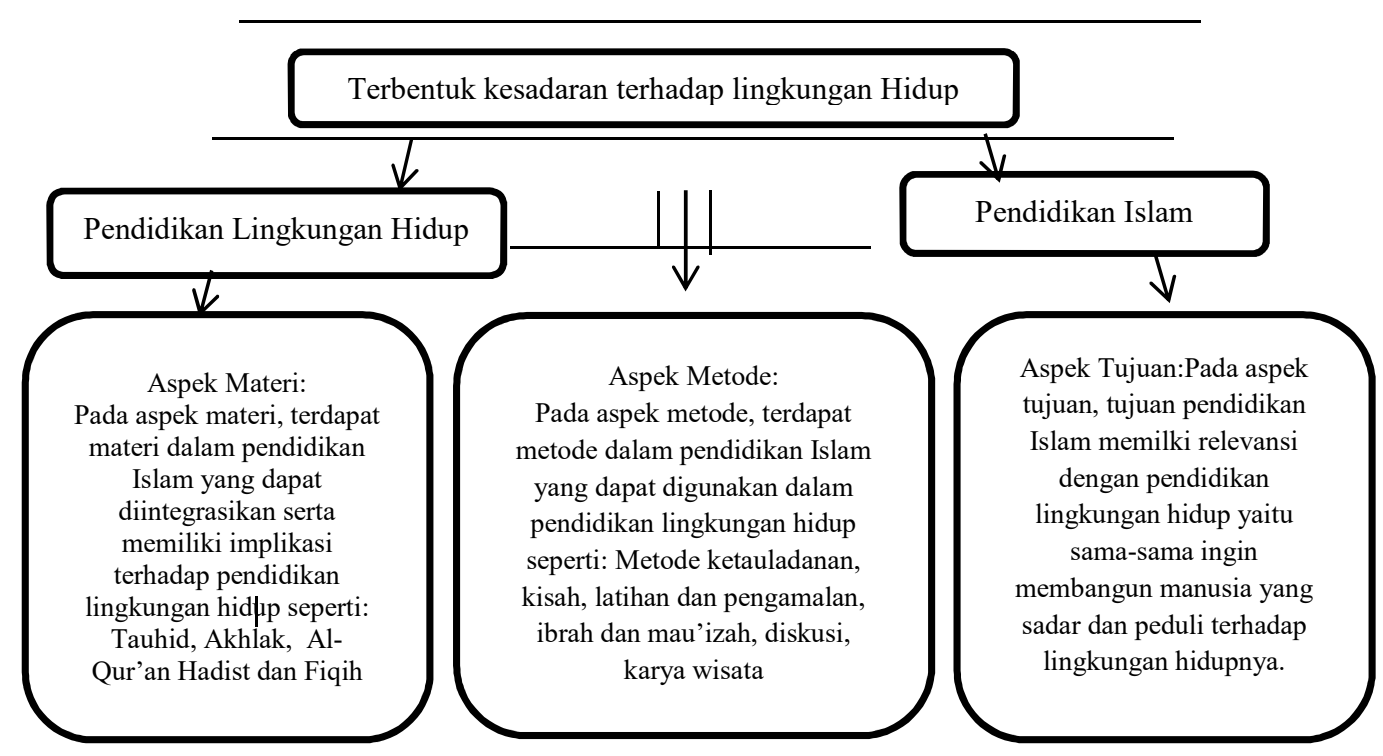

Gambar 3. Eksistensi Pendidikan Lingkungan Hidup dalam Pendidikan Islam

Berdasarkan gambaran eksistensi Pendidikan lingkungan hidup dalam ranah Pendidikan Islam di atas di ketahui bahwa ada beberapa hal yang dapat di deskiripsikan diantaranya adalah:

1. Aspek Materi

Berdasarkan kebijakan kurikulum yang saat ini diterapkan, materi pendidikan lingkungan hidup diajarkan kepada peserta didik dalam bentuk pembelajaran yang terintegrasi dengan pelajaran lainnya. Pada dasarnya, beberapa materi pada pembelajaran yang ada saat ini memiliki muatan pendidikan lingkungan hidup terutama pada materi pendidikan Islam, pendidikan Islam menekankan keseimbangan, keselarasan, serta keserasian hubungan antara manusia dengan Allah SWT, hubungan manusia dengan sesama manusia, serta hubungan manusia 25 | Qiro'ah| Vol. 11 No. 22021 
dengan alam atau lingkungan sekitarnya sebagai bukti ketaatan kepada Allah SWT. Berikut ini materi-materi dalam pendidikan Islam yang dapat diintegrasikan serta memiliki implikasi dengan pendidikan lingkungan hidup:

a. Pendidikan Tauhid

Pendidikan Islam yang di dalamnya terdapat pendidikan tauhid memiliki implikasi terhadap pendidikan lingkungan hidup, seperti materi dalam pendidikan tauhid manusia diajarkan bahwa alam semesta ini tidak terbentuk dengan sendirinya, melainkan diciptakan. Pendidikan tauhid bisa menjadi media untuk menyadarkan manusia bahwasannya setiap tingkah laku manusia di dunia ini kelak akan dipertanggung jawabkan di pengadilan akhirat, jika hal itu sudah tertanam pada manusia, maka tebentuknya manusia yang sadar dan bertanggung jawab akan semakin besar serta mendalam. Kesadaran serta tanggung jawab itu akan mendorong manusia untuk senantiasa berbuat baik, baik itu terhadap dirinya, keluarga, dan masyarakat umum. Dengan demikian, dia akan menjaga lingkungan hidupnya agar kualitasnya dan kuantitasnya selalu terjaga tidak turun.

b. Akhlak

Tujuan pendidikan akhlak adalah untuk memberikan pedoman atau penerangan bagi manusia untuk mengetahui perbuatan baik dan buruk. Jika terhadap perbuatan baik ia berusaha untuk melakukannya, namun sebaliknya jika perbuatan tersebut buruk ia berusaha untuk meninggalkannya, sehingga terbentuklah insan kamil atau manusia yang paripurna. ${ }^{19}$ Sebagaimana yang telah disebutkan di atas untuk mencapai tujuan pendidikan akhlak, secara vertikal seseorang harus berhubungan dengan secara terus-menerus dengan Allah SWT, serta secara horizontal harus berhubungan dengan sesama manusia dan lingkungan hidupnya. Dalam berhubungan secara horizotal manusia memerlukan lingkungan hidup untuk kelangsungan hidupnya, hal tersebut memberikan isyarat kepada manusia untuk tidak berbuat sewenang-wenang terhadap alam, sebab alam juga mahluk Allah sama seperti manusia. Untuk itu rasa perikemahlukan harus di tanamkan oleh pendidikan akhlak kepada peserta didik.

c. Al Qur'an Hadist

Dalam konteks pelaksanaan pendidikan Islam yang terdapat di dalamnya pembelajaran Al-Qur'an Hadist, bisa untuk menjadi suatu upaya menanamkan pendidikan lingkungan hidup dengan cara diintegrasikan kedalam pembelajaran Al-Qur'an Hadist, karena banyak ayat-ayat Al-Qur'an maupun Hadist Nabi Muhammad Saw. yang membahas mengenai lingkungan hidup.

Lebih lanjut untuk mengintegrasikan pendidikan lingkungan hidup kedalam pembelajaran Al-Qur'an Hadist, materi yang diintegrasikan mengenai ayat-ayat Al-Qur'an ataupun Hadist Nabi Muhammad Saw. yang berkenaan

${ }^{19}$ Abudin Nata, Akhlak Tasawuf Dan Karakter Mulia (Jakarta: Raja Grafindo Persada, 2017).h.13

26 | Qiro'ah| Vol. 11 No. 22021 
dengan lingkungan hidup. Dengan harapan memahami isi kandungan pada AlQur'an maupun hadist Nabi, peserta didik dapat tersadar akan pentingnya berhubungan dengan baik dengan alam. Dan bisa untuk menjaga kelestarian pada lingkungannya, dengan mengamalkan nilai-nilai yang ada pada Al-Qur'an maupun Hadist Nabi Muhammad Saw..

\section{d. Fikih}

Fikih berbicara mengenai realita kehidupan manusia yang secara rinci dan bagaimana cara untuk menata kehidupan tersebut sebagai bagian dari mahluk hidup yang ada di alam ini, dari sudut pandang tersebut fikih ikut berbicara tentang masalah lingkungan hidup yang kini menjadi masalah global, yang disebut dengan fikih al-bi'ah atau fikih yang berwawasan lingkungan hidup.

Dalam konteks pendidikan Islam, fikih merupakan salah satu bagian pelajaran dari pendidikan Islam yang terdapat pada lembaga formal yang dapat diintegrasikan dan memiliki implikasi dengan pendidikan lingkungan hidup, karena dalam aspek materi terdapat materi-materi fikih yang memiliki hubungan yang erat pendidikan lingkungan hidup seperti pada materi thahrah (bersuci), shalat, dan puasa. Dan hubungan tersebut, harus disampaikan oleh pendidik agar peserta didik paham dimana letak hubungannya, sebagai upaya untuk membangaun peserta didik yang memiliki kesalehan ekologis.

2. Aspek Metode

Dalam konteks pendidikan lingkungan hidup yang diintegrasikan ke dalam pendidikan Islam, terdapat metode-metode dalam pendidikan Islam yang tepat digunakan untuk mengupayakan pengembangan dan penanaman nilai-nilai peduli terhadap lingkungan hidup dalam pendidikan Islam. Berikut ini beberapa metode dalam pendidikan Islam tersebut:
a. Metode ketauladanan
b. Metode kisah
c. Metode latihan dan pengamalan
d. Metode 'ibrah dan mau'izah
e. Metode diskusi
f. Metode karya wisata. $^{20}$

3. Aspek Tujuan

Dalam aspek tujuan pendidikan Islam, tujuan pendidikan lingkungan hidup memiliki suatu hubungan dengan tujuan pendidikan Islam, sebagaimana pendapat dari Muhammad Fadhil Al-Jamli yang dikutip oleh Bukhari Umar, bahwa tujuan

\footnotetext{
${ }^{20}$ Ghufron and Saharuddin, "Islam Dan Konservasi Lingkungan (Telaah Pemikiran Fikih Lingkungan Yusuf Al-Qardhawi).”h.108

27 | Qiro'ah| Vol. 11 No. 22021
} 
pendidikan Islam diantaranya yaitu mengenalkan manusia akan perannya di antara sesama titah mahluk dan tanggung jawabnya di dalam hidup ini, mengenalkan manusia akan alam dan mengajak mereka untuk mengetahui hikmah diciptakannya serta memberi kemungkinan kepada mereka untuk mengambil manfaat darinya. ${ }^{21}$

Lebih lanjut salah satu ciri dalam tujuan pendidikan Islam, yakni ingin membina serta mengarahkan potensi akal, jiwa dan raga, sehingga memiliki ilmu, serta keterampilan yang semua ini digunakan untuk menjalankan tugas pengabdiannya dan kekhalifaannya di bumi ini, dan mengarahkan manusia untuk menjadi khalifah di bumi dengan sebaik-baiknya, yaitu melaksanakan tugas-tugas memakmurkan dan mengolah bumi sesuai dengan kehendak Allah SWT. ${ }^{22}$ Oleh sebab itu, pada dasarnya tujuan pendidikan Islam ingin membentuk manusia yang dapat berhubungan dengan baik itu dengan penciptanya yaitu Allah SWT (Habblun Minnallah) dan hubungan dengan manusia (Habblun min an-nas), dan juga hubungan manusia dengan alam (Habblun min al-alam), untuk mencapai konsep manusia seutuhnya (Insan kamil) sesuai dengan tujuan pendidikan Islam.

Berdasarkan uraian di atas, mengenai tujuan pendidikan Islam dalam hubungannya dengan pendidikan lingkungan hidup, dapat dikatakan bahwa tujuan pendidikan Islam ingin memberi pemahaman kepada manusia akan perannya di bumi ini, dalam hal ini peran manusia adalah sebagai khalifah atau wakil Allah SWT, yang bertugas untuk mengelola alam ini dengan cara yang baik dan sesuai dengan ketentuan-ketentuan dari Allah SWT, Dan tidak melakukan tindakan perusakan di bumi ini.

${ }^{21}$ Umar, Ilmu Pendidikan Islam.

${ }^{22}$ A Rosmiyati Aziz, Ilmu Pendidikan Islam, 1st ed. (Yogyakarta: Si Buku, 2019).h.191

28 | Qiro'ah| Vol. 11 No. 22021 


\section{KESIMPULAN}

Sebagai negara yang mayoritas penduduknya adalah seorang muslim, terlihat bahwa agama Islam belum berperan maksimal dalam memberikan pengaruh pemikiran terhadap pendidikan lingkungan hidup. Oleh sebab itu, eksistensi pendidikan lingkungan hidup yang diimplementasikan dalam Pendidikan Islam hendaknya dapat di galakan pelaksanaannya dalam kehidupan sehari-hari. Namun, untuk merealisasikanya diperlukannya kerjasama agar tercapai dengan baik, baik dari pemerintah, pemuka agama dan pendidik. Pendidikan Islam dapat dijadikan sebagai media untuk merealisasikan nilai-nilai pendidikan lingkungan hidup, karena terdapat hubungan yang erat antara pendidikan lingkungan hidup dengan pendidikan Islam yaitu dari aspek materi, metode juga tujuan yang hasil akhirnya mencapai tujuan yaitu terbentuknya kesadaran setiap individu terhadap lingkungan hidup. Kendala utama dalam menyelamatkan lingkungan adalah kurangnya media untuk menanamkan kesadaran manusia akan perlunya pelestarian lingkungan hidup. Dalam hal ini pendidikan Islam dapat dijadikan sebagai media untuk pemecahannya.

\section{DAFTAR PUSTAKA}

Aziz, A Rosmiyati. Ilmu Pendidikan Islam. 1st ed. Yogyakarta: Si Buku, 2019.

Aziz, Erwati. "Upaya Pelestarian Lingkungan Hidup Melalui Pendidikan Islam." Yogyakarta: Pustaka Pelajar, 2013.

Daryanto, Daryanto, and Agung Suprihatin. Pengantar Pendidikan Lingkungan Hidup. Yogyakarta: Gava Media, 2013.

Fathoni, Abdurrahmat. Metodologi Penelitan Dan Penyusunan Skripsi. Jakarta: Rineka Cipta, 2011.

Ghufron, Aziz, and Saharudin Saharuddin. "Islam Dan Konservasi Lingkungan (Telaah Pemikiran Fikih Lingkungan Yusuf Al-Qardhawi)." Millah VI, no. 2 (2007): 55-75.

Hamzah, Syukri. "Pendidikan Lingkungan: Sekelumit Wawasan Pengantar." Bandung: Refika Aditama, 2013.

Khaeron, Herman. Islam, Manusia, Dan Lingkungan Hidup: Kontekstualisasi Ajaran Islam Dalam Mengelola Alam Semesta. Edited by Irwan Kurniawan. 1st ed. Bandung: Nuansa Cendikia, 2014.

Matin, Ibrahim Abdul. Greendeen: Inspirasi Islam Dalam Menjaga Dan Mengelola Alam. 1st ed. Jakarta: Zaman Press, n.d.

Mawardi, Muhiddin, Gatot Supangkat, and Miftahulhaq Miftahulhaq. "Akhlaq Lingkungan: Panduan Berperilaku Ramah Lingkungan." Kementerian Lingkungan Hidup 1 (2011):56.

Nata, Abudin. Akhlak Tasawuf Dan Karakter Mulia. Jakarta: Raja Grafindo Persada, 2017.

Purwidianto, Purwidianto. "Pendidikan Lingkungan Hidup Dalam Perspektif Islam."
Jurnal
UHAMKA
8, no.
2
(2017):
205-28. 
https://doi.org/10.36835/syaikhuna.v11i1.3844.

Qardhawi, Yusuf. Riayah Al Bi'ah Fi Syari'ati Al-Islam. Cairo: Daar al-Syuruq, 2001.

Sulistiyo, Agus. "Konsep Pendidikan Lingkungan Hidup Dalam Pandangan Islam."

Jurnal Cahaya Pendidikan 4, no. 1 (2018). https://doi.org/https://doi.org/10.33373/chypend.v4i1.1281.

Umar, Bukhari. Ilmu Pendidikan Islam. 1st ed. Jakarta: Amzah, 2018.

Yafie, Ali. Merintis Fiqh Lingkungan Hidup. Edited by Marzuki Wahid, Helmy Ali, and Marya Ulfa. 1st ed. Jakarta: Yayasan Amanah Ufuk Press, 2016. 